\title{
Phosphoprotein F1: Purification and Characterization of a Brain Kinase C Substrate Related to Plasticity
}

\author{
S. Y. Chan, K. Murakami, and A. Routtenberg \\ Cresap Neuroscience Laboratory, Northwestern University, Evanston, Illinois 60201
}

To study the role of protein kinase $\mathrm{C}$ (PKC) and its substrates in neuronal function, we have investigated the in vitro endogenous phosphorylation of the neuronal phosphoprotein F1 after induction of synaptic plasticity by long-term potentiation (LTP). The protein $F 1$ phosphorylation was found to increase 5 min (Routtenberg et al., 1985), 1 hr (Lovinger et al., 1986) and 3 d (Lovinger et al., 1985) after LTP. The characteristics of this protein bear close similarities to a number of proteins characterized in various neuronal systems, such as B50 (brain specific, synaptosome-enriched protein), pp46 (a growth cone protein), and GAP 43 (nerve growth and regeneration-associated protein). A positive identification of the purified protein $F 1$ with these proteins would link protein F1 to the developmental growth of axons, nerve regeneration, and polyphosphoinositide metabolism, as well as adult plasticity.

We have therefore purified and partially characterized native protein $F 1$ so that a meaningful comparison among the properties of these proteins can be made. Using synaptosomal plasma membrane $\left(\mathbf{P}_{2}^{\prime}\right)$ as starting material, subsequent purification involved pH extraction, $40-80 \%$ ammonium sulfate precipitation, hydroxylapatite, and phenyl-Sepharose column chromatography. This procedure achieved greater than 800 -fold purification and about $45 \%$ yield relative to $P_{2}^{\prime}$. Purified protein F1 $\left(M_{\mathrm{r}}=47,000, \mathrm{pI}=4.5\right)$ was found to be a hydrophilic molecule and was phosphorylated by 1000 -fold purified PKC in the presence of phosphatidylserine (PS) and $\mathrm{Ca}^{2+}$. The $K_{\mathrm{a}}$ of PS activation is about $15 \mu \mathrm{g} / \mathrm{ml}(\sim 20 \mu \mathrm{M})$, and that of $\mathrm{Ca}^{2+}$ is about $25 \mu \mathrm{M}$. Diolein and DiC:8 (a synthetic diacylglycerol) lowered the requirement of $\mathrm{Ca}^{2+}$ for maximal stimulation from 100 to 5 $\mu \mathrm{M}$. $\mathrm{Ca}^{2+}$-calmodulin kinases type I and II did not phosphorylate protein $F 1$. The phosphoamino acid analysis showed that 97\% of the total incorporated ${ }^{32} \mathrm{P}$-phosphate was on the serine residue. Phosphopeptide mapping using V8-protease generated 2 phospho-fragments having apparent $M_{\mathrm{r}}$ of 13,000 and 11,000. Calmodulin at $3.6 \mu \mathrm{M}$ inhibited $95 \%$ of protein F1 phosphorylation by $P K C$. The availability of purified native protein $F 1$ should facilitate investigation of the physiological role of this protein in the nervous system and its functional regulation by PKC.

It has been demonstrated in non-neuronal systems that protein kinase $\mathrm{C}(\mathrm{PKC})$ is a multifunctional regulatory enzyme capable of phosphorylating multiple substrates that then give rise to a variety of cellular responses (for review, see Nishizuka, 1984a,

\footnotetext{
Received Jan. 29, 1986; revised June 10, 1986; accepled June 10, 1986.

' We thank R. Nelson for valuable discussion and help in the preparation of 2-dimensional gels, C. Haskell and $\mathbf{M}$. Whiteley for skillful technical assistance, and P. Naumann for computer assistance. Special thanks to Dr. S. Squimto and Dr. R. A. Jungmann for help in phosphoamino acid analysis. We are also indebted to Dr. M. B. Kennedy for providing us with purified type II Ca-calmodulin kinase and synapsin I. This research was supported by NIMII Grant MII25281-12 and Grant AFSOR83-0335 (A.R.).

Correspondence should be addressed to Dr. A. Routtenberg at the above address. Copyright (C) 1986 Society for Neuroscience $0270-6474 / 86 / 123618-10 \$ 02.00 / 0$
}

b). For example, the PKC phosphorylation of human epidermal growth factor receptor (EGF-R) from A431 epidermoid carcinoma cells caused an inhibition of tyrosine kinase activity of the receptor (Davis et al., 1985a; Hunter et al., 1984) and stimulated the mitogenic response of cultured A431 cells (Davis et al., 1985b). The PKC phosphorylation of a 40,000 Da human platelet protein, on the other hand, was found to correlate closely with thrombin-induced 5-HT secretion in platelets (Imaoka et al., 1983; Kawahara et al., 1980).

The functional role of PKC and its substrates in neuronal systems is not well understood, and the study of PKC-mediated events in nervous tissue has only recently been developed. Previous observations in our laboratory indicated that the phosphorylation state of a membrane-bound $47,000 \mathrm{Da}$ protein, termed protein $F 1$ in rat brain, was selectively altered after longterm potentiation (Lovinger et al., 1985, 1986; Routtenberg et al., 1985), a physiological model for synaptic plasticity. It was found that protein F1 was an endogenous PKC substrate in crude synaptosomal plasma membranes (Akers and Routtenberg, 1985) and that cytosolic PKC activity was translocated to plasma membrane after long-term potentiation (Akers et al., 1986). Recently, iontophoretic application of phorbol ester (PMA), a PKC activator, to the hippocampus was demonstrated to prolong the enhanced synaptic response (Routtenberg et al., 1986). These results have led us to suggest that protein $F 1$ and PKC may be involved in long-term modulation of synaptic efficacy (for review, see Routtenberg, 1985a, b, 1986).

Investigation of specific functions requires analysis of protein $\mathrm{F} 1$ and kinase $\mathrm{C}$ in sufficiently purified form for structure-function and kinetic studies. To date, protein F1 (Nelson and Routtenberg, 1985) and F1-like proteins such as GAP43 (Skene and Willard, 1981a) or B50 protein (Oestreicher et al., 1983) have been isolated only in a denatured form by SDS-PAGE or isoelectrofocusing techniques. In the present work, we describe the purification of native protein $\mathrm{F} 1$ from rat brain and report some of the physicochemical characteristics of this protein.

\section{Materials and Methods}

\section{Materials}

Male Sprague-Dawley rats, 200-250 gm, were purchased from Harlan Farm, IN. Diolein and DiC:8 were obtained from Life Science Resources; phenyl-Sepharose CL-4B from Pharmacia Fine Chemicals; acrylamide, $N-N$-methylenebisacrylamide, Bio-gel P-100, and hydroxylapatite from Bio-Rad; ampholine from LKB; $N, N, N^{\prime}, N^{\prime}-$ tetramethylethylenediamine and Kodak AR x-ray film from Eastman Kodak; and $\gamma_{-}{ }^{32}$ P-ATP from ICN pharmaceuticals. All other chemical reagents were purchased from Sigma. All reagents were analytical grade.

\section{Methods}

Preparation of crude synaptosomal membrane fraction $\left(P_{2}^{\prime}\right)$ $\mathrm{P}_{2}{ }^{\prime}$ fractions were prepared by a modification of the procedure of De Robertis et al. (1967) as described in Akers and Routtenberg (1985). 
All operations were done at $4^{\circ} \mathrm{C}$ unless otherwise specified. Twelve rat cortices $(\sim 12 \mathrm{gm})$ were homogenized in $60 \mathrm{ml}$ of ice-cold $0.32 \mathrm{M}$ sucrose and 2 mм DTT using a motorized homogenizer (10 strokes). After resuspension with another $60 \mathrm{ml}$ of the same solution, the homogenate was centrifuged at $1000 \times g$ in a Sorvall RC-5B refrigerated centrifuge for $10 \mathrm{~min}$. The supernatant was subjected to a higher spin of $12,000 \times$ $g$ for $20 \mathrm{~min}$ before the pellet $\left(\mathrm{P}_{2}\right)$ was resuspended in $60 \mathrm{ml}$ of lysing buffer containing $10 \mathrm{~mm}$ EGTA and 2 mм DTT, pH 7.5. After $45 \mathrm{~min}$ of slow stirring, the suspension was spun at $17,500 \times \mathrm{g}$ for $20 \mathrm{~min}$. The supernatant (synaptosomal cytosol) was saved in early experiments for testing protein $\mathrm{F} 1$ and $\mathrm{PKC}$ activities but was discarded in later preparations. The pellet $\left(\mathrm{P}_{2}{ }^{\prime}\right)$ was resuspended in $10 \mathrm{ml}$ of $1 \mathrm{~mm} \mathrm{Mg}$-acetate.

\section{Solubilization of Protein F1}

The $\mathrm{pH}$ extraction of $\mathrm{F} 1$ from the $\mathrm{P}_{2}^{\prime}$ membrane fraction was similar to the process described by Oestreicher et al. (1983). Briefly, the resuspended $\mathrm{P}_{2}{ }^{\prime}$ was adjusted to $\mathrm{pH} 11.5$ with $1 \mathrm{~N} \mathrm{NaOH}$. The alkali extract was centrifuged at $130,000 \times g$ in a Beckman L2-658 ultracentrifuge for $30 \mathrm{~min}$. The precipitate was discarded, while the supernatant was acidified to $\mathrm{pH} 5.5$ with $1 \mathrm{M} \mathrm{Na}$ acetate-acetic acid, $\mathrm{pH} 5.0$. The fraction was centrifuged at $58,000 \times g$ for $20 \mathrm{~min}$. The supernatant, containing solubilized $\mathrm{F} 1$, was subjected to $40-80 \%$ ammonium sulfate precipitation. The final precipitate was spun down at $58,000 \times g$ for $20 \mathrm{~min}$, resuspended in a minimal amount of $5 \mathrm{mM} \mathrm{KPi} \mathrm{+} 1$ mM EDTA buffer, $\mathrm{pH} 7.5$, and dialyzed overnight against the same buffer. All purification procedures were done at $4^{\circ} \mathrm{C}$ unless otherwise specified.

\section{Purification of protein kinase $C$}

Using a modified procedure of Kikkawa et al. (1982), protein kinase C was purified in our laboratory to apparent homogeneity (Murakami and Routtenberg, 1985). Whole forebrains from 24 rats were homogenized with a motorized homogenizer and centrifuged at $100,000 \times g$ for $1 \mathrm{hr}$. cAMP, $40 \mu \mathrm{M}$, was added to the supernatant to eliminate cAMP-dependent protein kinase (Lubben and Traugh, 1983) before it was applied to a DEAE-cellulose column $(2.5 \times 16 \mathrm{~cm})$, eluted with $0-0.3 \mathrm{M} \mathrm{NaCl}$. The active fraction was concentrated and subjected to an AcA34 gelfiltration column $(2.5 \times 95 \mathrm{~cm})$. The enzyme fraction was further purified using a hydroxylapatite column $(1.5 \times 2.5 \mathrm{~cm})$ followed by a phenyl-Sepharose column $(1 \times 2 \mathrm{~cm}, 2-0 \mathrm{M} \mathrm{NaCl}$ continuous gradient $)$. The PKC activity was assayed by measuring the incorporation of ${ }^{32} \mathrm{P}$ ATP into lysine-rich histone $\mathrm{Hl}$ (type III-S). The typical specific activity of the purified PKC used was about $650 \mathrm{nmol} / \mathrm{min} / \mathrm{mg}$ protein. PKC activity was assayed essentially as in Murakami and Routtenberg (1985). The standard reaction mixture (final volume, $240 \mu \mathrm{l}$ ) contained $300 \mu \mathrm{g} /$ $\mathrm{ml}$ histone, $500 \mu \mathrm{M} \mathrm{Ca}^{2+}, 5 \mathrm{mM} \mathrm{Mg}^{2+}$, and $30 \mu \mathrm{g} / \mathrm{ml}$ PS in $50 \mathrm{~mm}$ Tris, $\mathrm{pH}$ 7.5. The reactions were initiated by adding $20 \mu \mathrm{l}$ of $2 \mathrm{~mm}$ ATP (specific activity $100-150 \mathrm{cpm} / \mathrm{pmol}$ ) and were carried out up to $10 \mathrm{~min}$ at $30^{\circ} \mathrm{C}$. The reactions were terminated with $50 \mu \mathrm{l}$ of EGTA and EDTA saturated solution, and $200 \mu \mathrm{l}$ of the reacted sample was spotted onto Whatman P-81 phosphocellulose paper. The paper was washed, and the radioactivity was counted with a Beckman LS 150 scintillation counter.

\section{Standard assays of protein $F 1$ phosphorylation}

Protein F1 served as a substrate for purified or partially purified PKC (after the AcA34 gel filtration step) in the presence of phosphatidylserine (PS), $\mathrm{Ca}^{2+}$, and $\mathrm{Mg}^{2+}$. The in vitro assay mixture (final volume, 60-110 $\mu \mathrm{l})$ contained $2.5 \mathrm{mM} \mathrm{Mg}{ }^{2+}, 200 \mu \mathrm{M} \mathrm{Ca}{ }^{2+}$, and $100 \mu \mathrm{g} / \mathrm{ml} \mathrm{PS}$ in $50 \mathrm{~mm}$ Tris, pH 7.5. The appropriate amount of PKC (about $60 \mathrm{pmol} / \mathrm{min}$ protein kinase activity) and various preparations of protein F1 were added before preincubation at $30^{\circ} \mathrm{C}$ for $1 \mathrm{~min}$. Ten microliters of ${ }^{32} \mathrm{P}$ ATP (final concentration, $5 \mu \mathrm{M}$; specific activity, $1.5-3 \times 10^{5} \mathrm{cpm} / \mathrm{nmol}$ ) were then added to start the reaction (usually $2 \mathrm{~min}$ at $30^{\circ} \mathrm{C}$ ). The reactions were terminated by the addition of a stop solution $(25 \mu \mathrm{l} / 100$ $\mu$ l sample volume containing $15 \%$ SDS, $10 \% \beta$-mercaptoethanol, $30 \%$ sucrose, $0.05 \%$ bromophenol blue, and $25 \mathrm{~mm}$ EDTA in $0.186 \mathrm{M}$ Tris $\mathrm{HCl}, \mathrm{pH}$ 6.7). The samples were then boiled for $5 \mathrm{~min}$ and subjected to $10 \%$ SDS-PAGE and autoradiography.

The cAMP-dependent kinase assay was performed according to Ueda and Greengard (1977) with some modifications. cAMP dependent kinase (Sigma), $5 \mu \mathrm{g}$, was incubated with $1 \mu \mathrm{g}$ of purified F1 or $10 \mu \mathrm{g}$ of synapsin I, $10 \mathrm{~mm} \mathrm{Mg}^{2+}, 5 \mu \mathrm{M}^{32} \mathrm{P}-\mathrm{ATP}$, and $50 \mathrm{~mm}$ Tris, $\mathrm{pH} 7.5$ (final volume, $70 \mu \mathrm{l}$ ) in the presence or absence of $20 \mu \mathrm{M}$ cAMP at $30^{\circ} \mathrm{C}$ for various time periods. Purified synapsin I was used as a control.
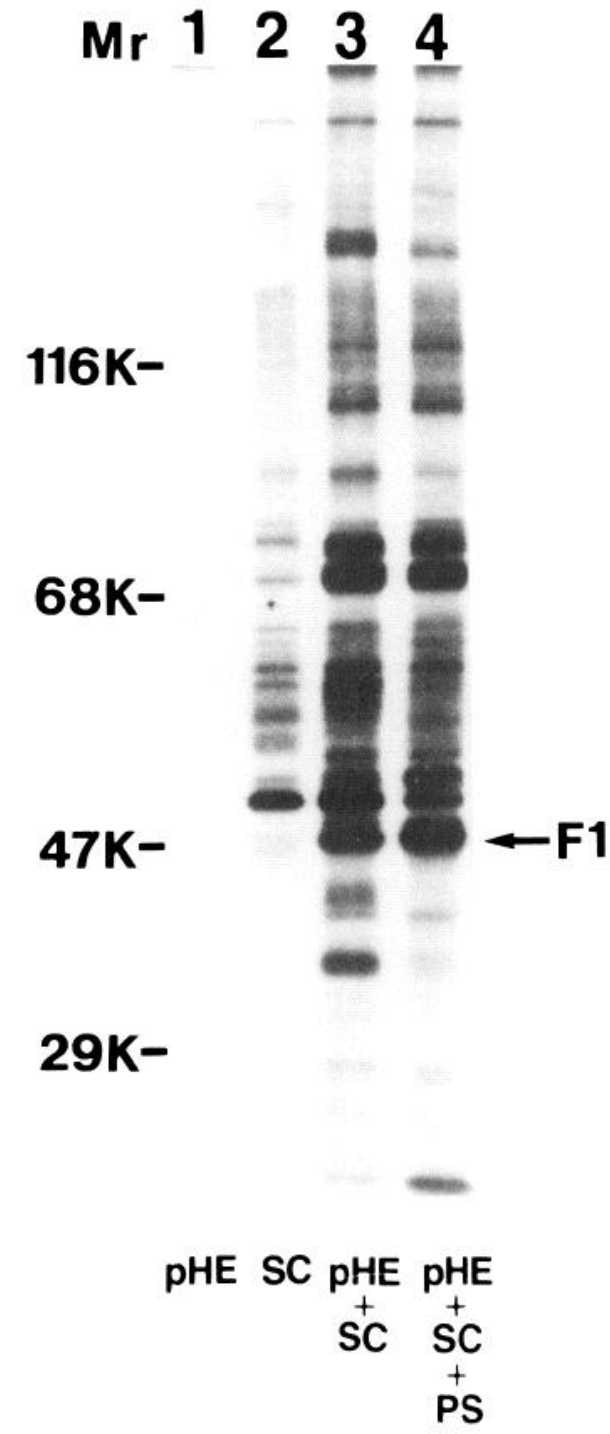

Figure 1. Autoradiograph showing synaptic membrane enrichment of protein $\mathrm{F} 1$. The pHE fraction, derived from $\mathrm{P}_{2}{ }^{\prime}$, did not contain any kinase activity (lane 1 ), while the synaptosomal cytosol $(S C)$ fraction did not contain protein F1 (lane 2). However, when the 2 fractions were combined, a phosphorylated band appeared right at the $47 \mathrm{kDa}$ region (lane 3). The phosphorylation of this protein band was further stimulated by the addition of $100 \mu \mathrm{g} / \mathrm{ml}$ PS (lane 4). Note that PS stimulates the phosphorylation of some substrates but inhibits that of others. Lanes 1 and 2 contain $25 \mu \mathrm{g}$ protein; lanes 3 and $4,50 \mu \mathrm{g}$ protein. The pHE fraction was precipitated with $80 \%$ ammonium sulfate before phosphorylation. The samples were phosphorylated for $15 \mathrm{sec}$ at $30^{\circ} \mathrm{C}$.

\section{SDS-PAGE, autoradiography and quantitative estimation of incorporation of ${ }^{32} P$-phosphate into protein}

Ten percent SDS-PAGE (1.5 mm thick) was performed according to the procedure of Laemmli (Ames, 1974). The electrophoresis was carried out in $0.05 \mathrm{~m}$ Tris, $0.384 \mathrm{~m}$ glycine buffer at $60 \mathrm{~V}$ until the bromphenol blue dye passed the $3 \%$ stacking gel (about $1 \mathrm{hr}$ ) and then at $160 \mathrm{~V}$ until the dye reached the bottom of the gel. Following electrophoresis, the slab gel was stained with Coomassie Brilliant Blue R250 and dried with a gel dryer (model 224, Bio-Rad). The dried gel was subjected to autoradiography using Kodak Royal X-Omat AR film. Microdensitometry was done as reported earlier (Morgan and Routtenberg, 1981). Autoradiographs were scanned with an EC-Apparatus 920 microdensitometer. Phosphorylation was expressed as total densitometric area (minus background) occupied by the peak corresponding to each individual protein. A computer program tailored to calculate the area and height 


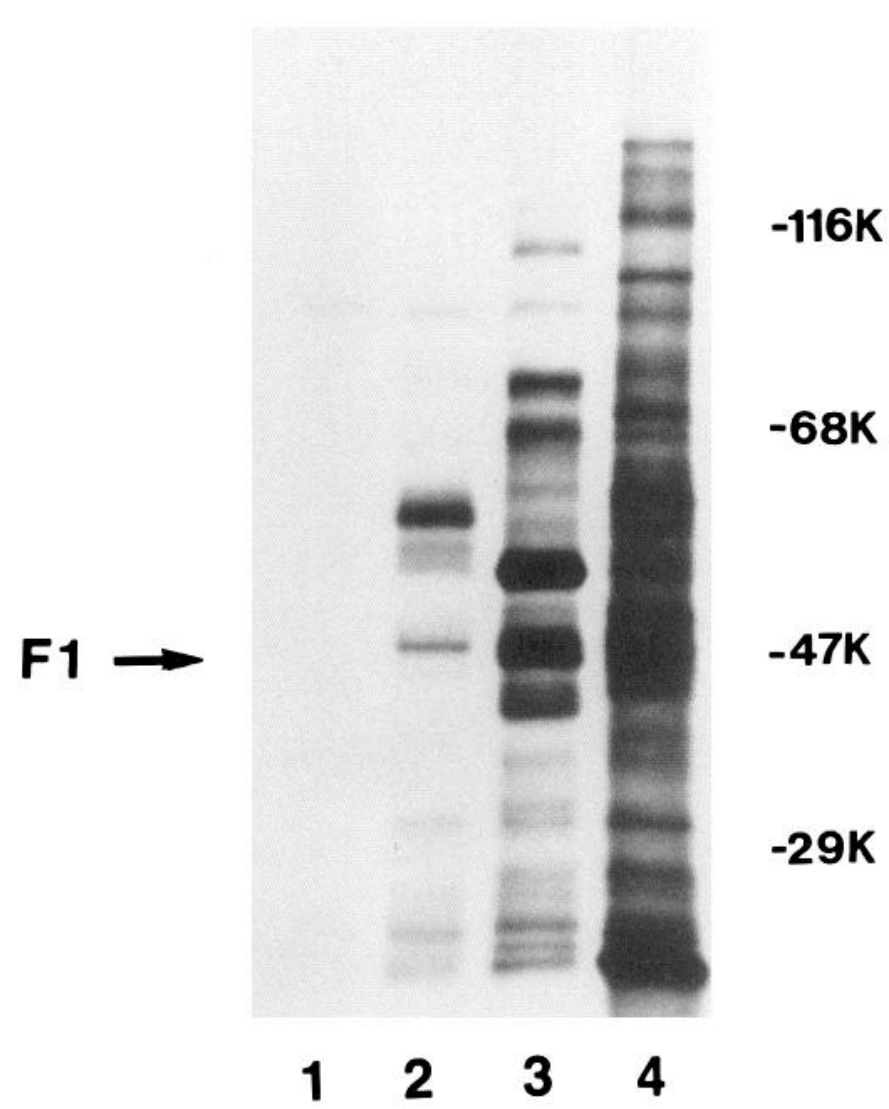

Figure 2. Autoradiograph showing the elution profile of phosphoproteins from the hydroxylapatite column. An aliquot of $60 \mu \mathrm{l}$ of each fraction was used for a 2 min reaction under standard phosphorylation conditions. Lanes $1-4$ represent fractions eluted from 0-5, 5-30, 3075 , and $75-400 \mathrm{~mm} \mathrm{KPi}, \mathrm{pH} 7.5$, gradient, respectively. Arrow indicates the expected position of protein F1.

under each peak was used in all analyses. Computer-assigned values were arbitrary but proportional to the intensities of protein phosphorylation within a given autoradiograph. The protein F1 band in some samples was cut off from the gel, using the autoradiograph as a guide; it was then eluted and the radioactivity was determined.

\section{Protein determination}

Protein determination was carried out by the method of Lowry et al. (1951) with BSA as the protein standard. For samples containing less than $0.05 \mathrm{mg} / \mathrm{ml}$ of protein, the amido black filtration assay (Schaffner and Weissmann, 1973) of protein determination was used.

\section{Two-dimensional electrophoresis (IEF-SDS)}

The isoelectrofocusing method of isoelectric point determination was carried out according to a modified procedure of O'Farrell et al. (1977). The IEF dimension was run on a modified Haake-Buchler Polyanalyst according to Nelson and Routtenberg (1985), in which the original grommets were replaced by serum caps with holes drilled to accommodate $200 \mu \mathrm{l}$ microcapillary pipettes (Fisher). The well-forming combs in the second dimension were custom-made to provide a wide center for the accommodation of the tube gels.

\section{Phosphoamino acid analysis}

Purified protein F1 was subjected to standard phosphorylation assay under optimal conditions; electrophoresis and autoradiography were as described above. The band identified as protein F1 was sliced out from the dried gel. After swelling and rinsing with distilled water, the cutoff band was smashed using a homogenizer piston and incubated at $37^{\circ} \mathrm{C}$ overnight in $250 \mu \mathrm{l}$ of $0.5 \%$ SDS. The sample was then spun in an Eppendorf microfuge (model no. 5413) for $5 \mathrm{~min}$, and the supernatant was removed. The pellet and $25 \mu \mathrm{l}$ of the supernatant were counted in a scintillation counter in order to estimate the extraction efficiency. The rest of the supernatant was lyophilized before treatment with $100 \mu \mathrm{l}$ of $10 \mathrm{mg} / \mathrm{ml}$ protease $\mathrm{K}$ in $50 \mathrm{~mm}$ Tris, $\mathrm{pH} 7.5$, at $37^{\circ} \mathrm{C}$ overnight. The digested sample was lyophilized again, and $250 \mu \mathrm{l}$ of $6 \mathrm{~N} \mathrm{HCl}$ was then added to hydrolyze the peptides at $110^{\circ} \mathrm{C}$ for $6 \mathrm{hr}$. The hydrolysates were lyophilized and resuspended with $30 \mu \mathrm{l}$ of distilled water containing $1 \mathrm{mg} / \mathrm{ml}$ each of phosphoserine, phosphotyrosine, and phosphothreonine. The samples were subjected to paper electrophoresis in a $4 \%$ acetic acid, $0.9 \%$ formic acid buffer, $\mathrm{pH} 2.4$, at $500 \mathrm{~V}$ for $16 \mathrm{hr}$, using a Beckman model R paper electrophoresis cell (Miles et al., 1981). The electrophoresed samples were stained with $1 \%$ ninhydrin and subjected to autoradiography. Stained phosphoserine, phosphotyrosine, and phosphothreonine bands were then cut off for scintillation counting to obtain a quantitative comparison of the phosphoamino acids.

\section{Phosphopeptide mapping}

The procedure for 1-dimensional phosphopeptide mapping on purified protein F1 was modified from Cleveland et al. (1977). Phosphorylated F1 was sliced out and eluted as noted in the previous section, except that distilled $\mathrm{H}_{2} \mathrm{O}$ was used instead of $0.5 \%$ SDS. After elution, the samples were lyophilized and resuspended in $50 \mu \mathrm{l}$ of $200 \mu \mathrm{g} / \mathrm{ml}$ Staphylococcus aureus $\mathrm{V}-8$ protease in a $50 \mathrm{~mm}$ Tris buffer, $\mathrm{pH} 7.5$. The proteolysis was allowed to proceed for $2 \mathrm{hr}$ at $37^{\circ} \mathrm{C}$. After proteolysis, the samples were loaded onto a $20 \%$ SDS-PAGE (bis: acryl $=1: 100$ ) and electrophoresed as described for the $10 \%$ gels.

\section{Results}

\section{Purification scheme}

Procedures prior to $40-80 \%$ ammonium sulfate precipitation were described above. The criteria for identification of protein F1 are its molecular mass, isoelectric point, and ability to serve as a protein kinase $\mathrm{C}$ substrate.

Protein F1 is enriched in the synaptosomal membrane fraction $\left(\mathrm{P}_{2}{ }^{\prime}\right)$. Figure 1 shows the effective lysing procedure of $\mathrm{P}_{2}$ using $10 \mathrm{~mm}$ EGTA to retain protein $\mathrm{F} 1$ in the $\mathrm{P}_{2}{ }^{\prime}$ membrane. $\mathrm{pHE}$ was the fraction obtained from $\mathrm{pH}$ extraction procedure described in Materials and Methods and was derived from $\mathrm{P}_{2}^{\prime}$. The $\mathrm{pH}$ extraction procedure deactivated all endogenous kinases (Fig. 1; Ueda and Greengard, 1977). All subsequent steps, therefore, required exogenous kinase $\mathrm{C}$ for the phosphorylation of protein $\mathrm{F} 1$. The supernatant of lysed $\mathrm{P}_{2}$ (synaptosomal cytosol, SC), though containing kinase C activity (specific activity, 96 $\mathrm{nmol} / \mathrm{min} / \mathrm{mg}$ protein, using histone as the substrate protein), did not show substantial endogenous phosphorylation in the 47,000 Da region, while the combined pHE and SC fractions showed PS-enhanced phosphorylation of protein F1 (Fig. 1).

Further purification after the ammonium sulfate precipitation step was achieved by hydroxylapatite (HP) fractionation. The resuspended precipitate was dialyzed overnight against a $5 \mathrm{~mm}$ $\mathrm{KPi}+1 \mathrm{~mm}$ EDTA buffer, $\mathrm{pH} 7.5$, before being applied to a $1.5 \times 4.2 \mathrm{~cm}$ HP column previously equilibrated with $5 \mathrm{~mm}$ $\mathrm{KPi}, \mathrm{pH} 7.5$. Three bed volumes of each step gradient $(30,75$, and $400 \mathrm{~mm} \mathrm{KPi}, \mathrm{pH} 7.5$ ), in increasing concentrations, were applied sequentially to the column at a flow rate of about 10 $\mathrm{ml} / \mathrm{hr}$, and 1-bed-volume fractions were collected. Protein F1 was detected using the standard in vitro phosphorylation assay, followed by $10 \%$ SDS gel electrophoresis and autoradiography, as described in Materials and Methods.

Protein F1 was found to elute from the HP column between 30 and $75 \mathrm{~mm} \mathrm{KPi}$. The results were later confirmed by 2-dimensional electrofocusing gels (see Fig. 8). Figure 2 shows the profiles of phosphoproteins eluted from HP fractionation by step gradients of $\mathrm{KPi}$. Most of the phosphoproteins were eluted in the 75-400 mM KPi eluate, but considerable amounts of phosphoproteins were still present in the $30-75 \mathrm{~mm} \mathrm{KPi}$ eluate. Typically, the second fraction of each step gradient contained the most protein and was used to represent the respective gradient elution.

The second and third fractions of the HP $30-75 \mathrm{~mm} \mathrm{KPi}$ 
Mr
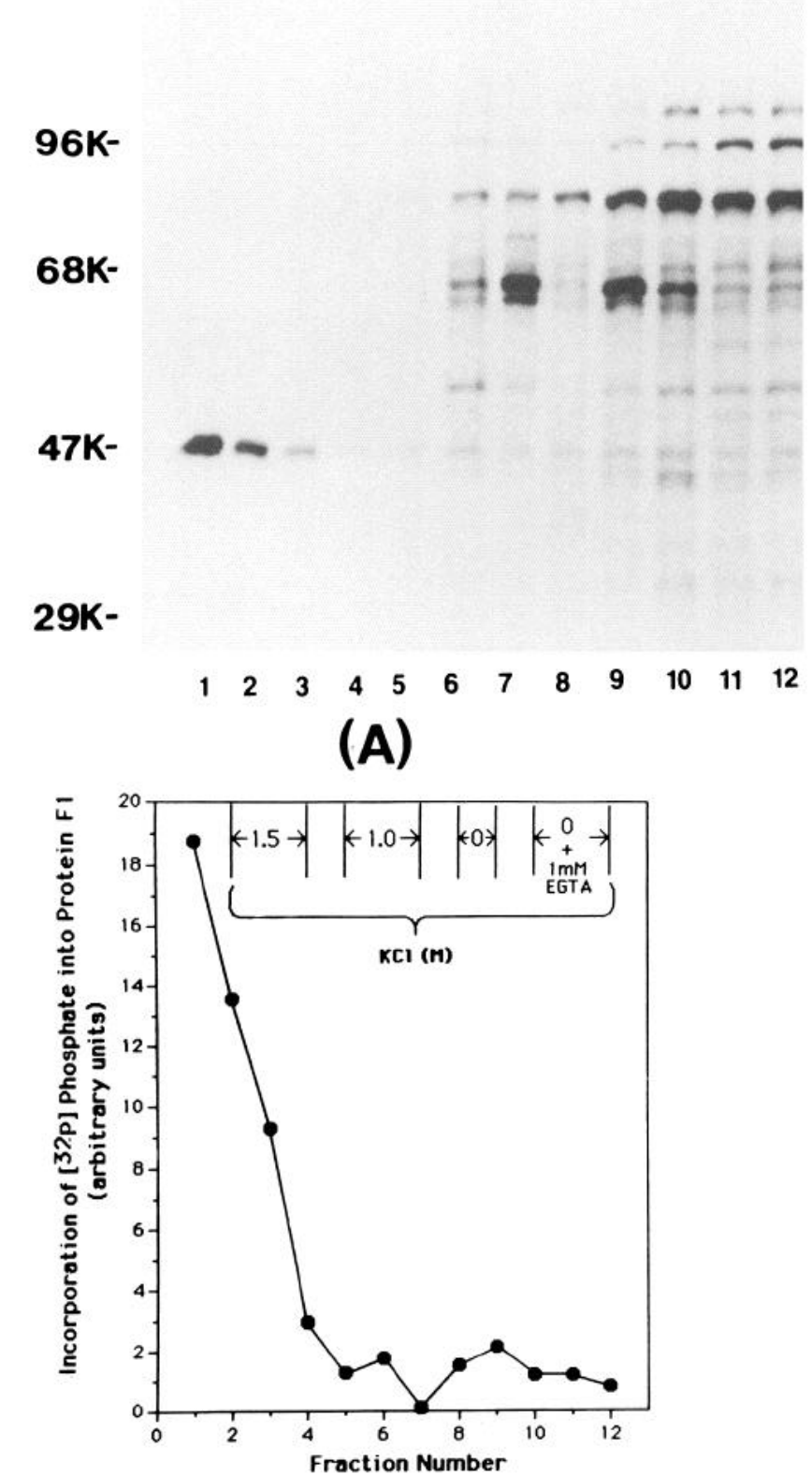

(B)

Figure 3. Elution profile of phenyl-Sepharose column. A, Autoradiograph showing the elution profile of phosphoproteins and protein F1 elution. Fraction 1 was the elution volume of excluded material. Fractions $2-12$ represent $\mathrm{KCl}$ gradients as indicated in $B$. Aliquots of $60 \mu \mathrm{l}$ of each fraction were used for phosphorylation under standard conditions. $B$, Densitometric measurement of $A$ showing that over $40 \%$ of total phospho-F1 was eluted at the void volume and the rest in the first 2 fractions of the $1.5 \mathrm{M} \mathrm{KCl}$ gradient.

gradient eluate were combined and applied to a phenyl-Sepharose CL-4B hydrophobic column $(1 \times 2.5 \mathrm{~cm})$ previously equilibrated with $2 \mathrm{M} \mathrm{KCl}$ in $50 \mathrm{~mm}$ Tris, $\mathrm{pH} 7.5 . \mathrm{KCl}, 1.5 \mathrm{M}$, was added to the HP eluate before loading. Three bed volumes of each step gradient $(1.5 \mathrm{M} \mathrm{KCl}, 1 \mathrm{~m} \mathrm{KCl}, 0 \mathrm{M} \mathrm{KCl}$, and $1 \mathrm{~mm}$ EGTA, all containing $20 \mathrm{~mm}$ Tris, $\mathrm{pH} 7.5$ ) were applied, in decreasing concentrations of $\mathrm{KCl}$, at a flow rate of $10 \mathrm{ml} / \mathrm{hr}$, and 1-bed-volume fractions were collected.

Since protein $\mathrm{F} 1$ is found in a membrane fraction and phenylSepharose preferentially binds to the hydrophobic region of protein molecules (Walsh et al., 1984), it was expected that it would

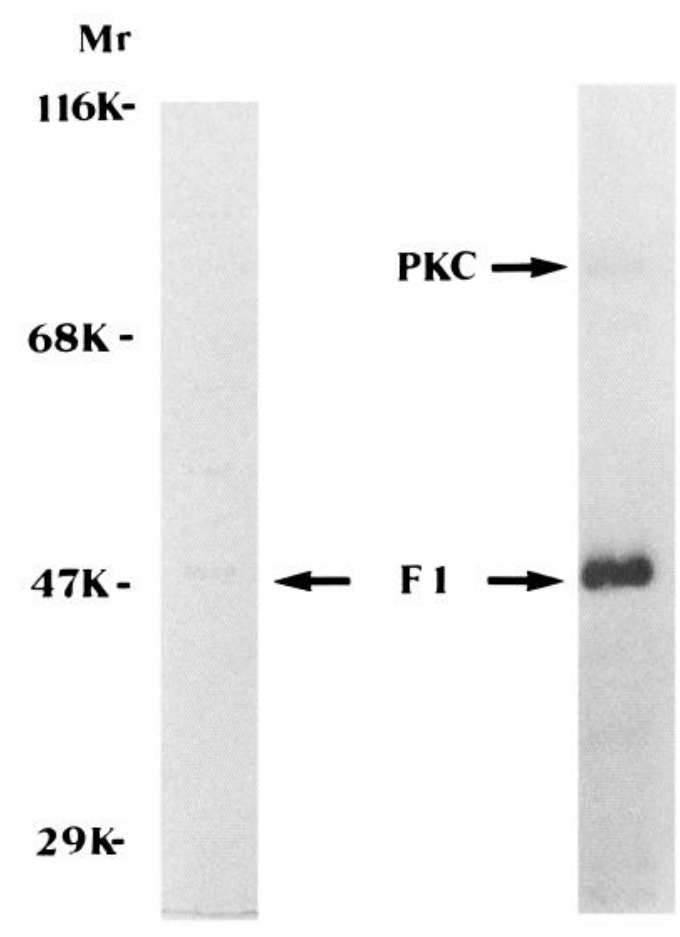

$\underline{\mathbf{A}}$

B

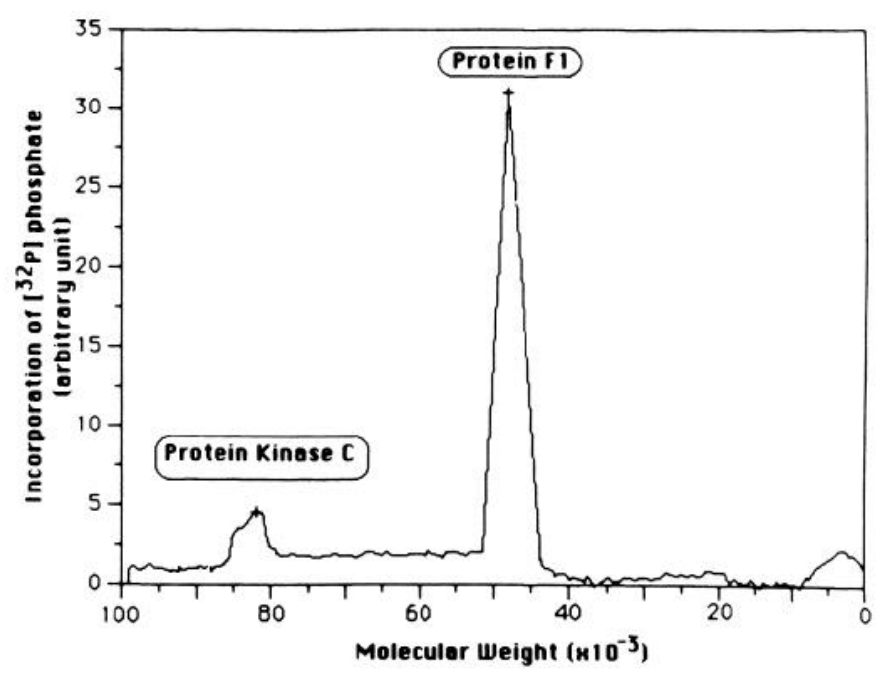

C

Figure 4. Purified fractions of protein F1. A, Coomassie-stained gel of a phenyl-Sepharose-purified fraction; approx. $2 \mu \mathrm{g}$ protein. Protein F1 was identified by its apparent molecular weight, autoradiography, and subsequent isoelectrofocusing. $B$, Corresponding autoradiograph. Arrows indicate the expected positions of protein F1 and PKC. PKC autophosphorylation was sometimes seen in phosphorylated samples. Occasionally there is a small amount of contaminating phosphoproteins from the PKC fraction. $C$, Densitometric scan of $B$.

bind to the column under hydrophobic conditions. However, protein $\mathrm{F} 1$ was eluted at the void volume and the first two fractions of $1.5 \mathrm{M} \mathrm{KCl}$ eluate (Fig. $3 A, B$ ), suggesting the highly hydrophilic nature of this molecule. Figure $3 A$ further showed 
Table 1. Purification of protein F1 from rat brain cortex ${ }^{a}$

\begin{tabular}{|c|c|c|c|c|c|c|}
\hline \multirow[b]{2}{*}{ Step } & \multirow{2}{*}{$\begin{array}{l}\text { Vol } \\
\text { (ml) }\end{array}$} & \multirow{2}{*}{$\begin{array}{l}\text { Protein } \\
(\mathrm{mg})\end{array}$} & \multirow{2}{*}{$\begin{array}{l}\text { Activity } \\
\text { (pmol) }\end{array}$} & \multirow{2}{*}{$\begin{array}{l}\text { Sp. act. } \\
\text { (pmol/mg } \\
\text { protein) }\end{array}$} & \multicolumn{2}{|c|}{$\begin{array}{l}\text { Purification } \\
\text { yield }\end{array}$} \\
\hline & & & & & Fold & $\%$ \\
\hline$P_{2}^{\prime}$ & 30 & 795 & 17,170 & 21 & - & - \\
\hline $\mathrm{pHE}^{c}$ & 20 & 31.4 & 17,170 & 546 & 26 & 100 \\
\hline $40-80 \% \mathrm{ASP}^{d}$ & 10 & 24 & 17,216 & 717 & 34 & 100 \\
\hline HP eluate $e^{e}$ & 22.5 & 1.5 & 10,146 & 6764 & 322 & 59 \\
\hline Ph.-Seph. eluate ${ }^{\prime}$ & 27 & 0.45 & 7780 & 17,290 & 823 & 45 \\
\hline
\end{tabular}

a Standard in vitro phosphorylation conditions as described in Materials and Methods.

${ }^{b}$ Activity was derived from densitometric scan. Arbitrary units were generated by a computer program according to the relative intensity of densitometric peaks in autoradiographs. The numbers were converted back to picomoles of incorporated phosphate as follows: Protein F1 was sliced from gel lanes containing the most purified fractions and counted for radioactivity. The cpm was coverted to picomoles of phosphate using the ${ }^{32} \mathrm{P}$-ATP stock used in the phosphorylation assay as a standard.

- The activity of $\mathrm{pHE}$ ( $\mathrm{pH}$-extracted fraction) was used for $\mathrm{P}_{2}^{\prime}$, assuming $100 \%$ recovery since there are numerous interfering factors in $\mathrm{P}_{2}^{\prime}$ and the phosphorylation conditions are drastically different from those of the other fractions.

${ }^{d}$ ASP, ammonium sulfate precipitated fraction.

' HP eluate, 30-75 mм KPi eluted fraction from hydroxylapatite column.

${ }^{f} \mathrm{Ph}$.-Seph. eluate, phenyl-Sepharose CL-4B column eluate containing protein F1.

that protein F1 was the only major PKC-dependent phosphoprotein present in these 3 fractions. All other phosphoproteins appeared in later fractions. Figure $3 B$ shows the corresponding densitometric measurements, indicating that $93 \%$ of total phospho-F1 was found in the first 3 fractions and about $40 \%$ was eluted in the first fraction alone. These 3 fractions, either separate or combined, were used in all subsequent experiments unless otherwise specified.

The hydrophobicity of proteins such as calmodulin (Gopalakrishna and Anderson, 1982) or PKC (Walsh et al., 1984) changes when $\mathrm{Ca}^{2+}$ is present. However, the addition of $1 \mathrm{~mm}$ $\mathrm{Ca}^{2+}$ to the HP fraction, when applied to the phenyl-Sepharose column and subsequently eluted with gradients containing $1 \mathrm{~mm}$ $\mathrm{Ca}^{2+}$, did not change the elution pattern, indicating that the hydrophobicity of protein $\mathrm{F} 1$ was unaffected by $\mathrm{Ca}^{2+}$. A few contaminating proteins (a major band of 55,000 Da and some minor bands) were still present in the phenyl-Sepharose-purified fraction. Figure 4 shows a Coomassie-stained gel pattern of the purified fraction, the corresponding autoradiograph, and the densitometric scan.

An attempt to further purify protein F1 using a P-200 gel filtration column (exclusion limit, 200,000 Da) did not produce increased purity. Interestingly, protein F1 was eluted at the void volume of the column (data not shown). This raised the possibility that the copurified protein bands may belong to a macromolecular complex containing protein F1. The relationship of protein F1 to other peptides in these purified fractions remains to be elucidated.

Table 1 shows the typical results of purification and yield. Protein F1 appeared to be purified $>800 \times$ with respect to the $\mathrm{P}_{2}{ }^{\prime}$ membrane fraction and with a yield of $45 \%$. It was difficult to estimate the degree of purification before the $\mathrm{P}_{2}^{\prime}$ fraction due to numerous interfering factors such as endogenous PKC, excess phospholipids, phosphatases, and the inaccessibility to the membrane by PKC.

The partially purified protein $\mathrm{F} 1$ could be stored at $-20^{\circ} \mathrm{C}$ in Tris or phosphate buffers at $\mathrm{pH} 7.5$ for at least 2 months without losing substrate activity. Repeated freezing and thawing and lyophilization also did not seem to diminish its ability to serve as a PKC substrate.

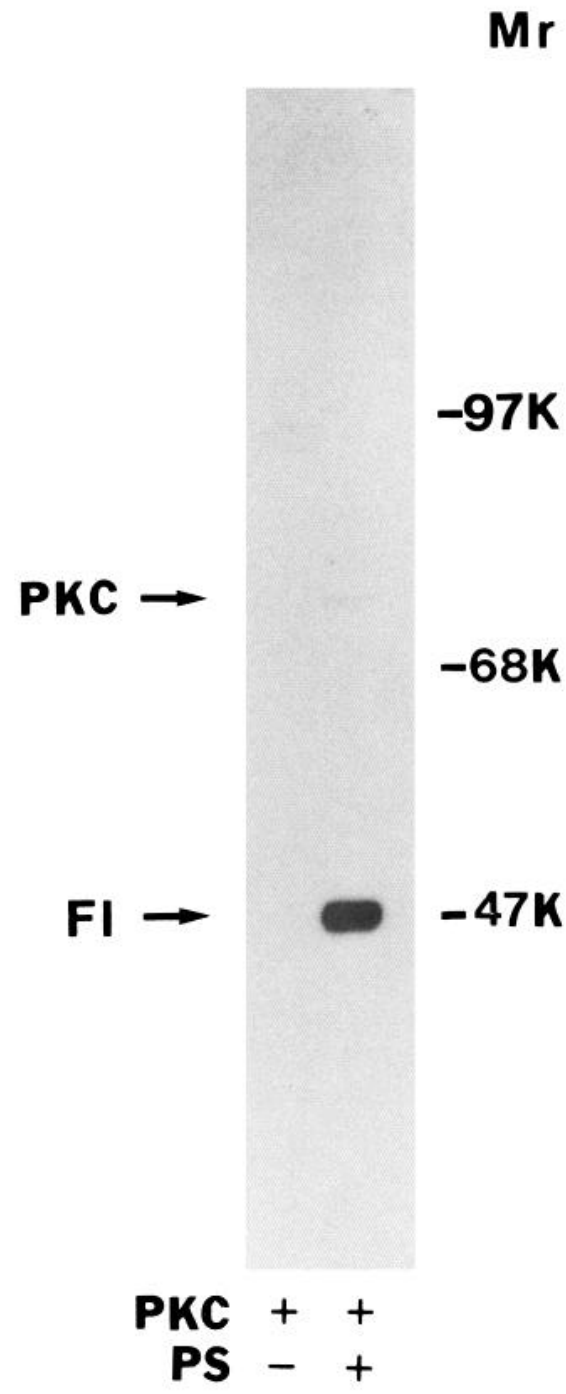

Figure 5. Autoradiograph showing phosphatidylserine (PS) dependency of F1 phosphorylation by PKC. Only when PKC and PS (100 $\mu \mathrm{g} / \mathrm{ml})$ were both present was $\mathrm{F} 1$ phosphorylation observed. In the absence of PKC, PS by itself did not phosphorylate F1 (data not shown). $\mathrm{Ca}^{2+}, 200 \mu \mathrm{M}$, and $\mathrm{Mg}^{2+}, 5 \mathrm{mM}$, were present in both samples. Reaction time was $1 \mathrm{~min}$ at $37^{\circ} \mathrm{C}$. Arrows indicated the expected positions of $\mathrm{PKC}$ and $\mathrm{F} 1$.

\section{Protein F1 as a protein kinase C substrate}

Protein F1 phosphorylation by purified, exogenous $\mathrm{PKC}$ was phosphatidylserine and $\mathrm{Ca}^{2+}$ dependent. Figure 5 shows the PS requirement for F1 phosphorylation. The $K_{\mathrm{a}}$ of PS activation is about $15 \mu \mathrm{g} / \mathrm{ml}$ (about $19 \mu \mathrm{M}$, assuming an average molecular weight of PS $=800$; Fig. $6 A$ ), in good agreement with the $K_{\mathrm{a}}$ of PS when histone was used as a substrate (Murakami and Routtenberg, 1985), and that of $\mathrm{Ca}^{2+}$ is about $25 \mu \mathrm{M}$ (Fig. $6 B$ ), using the densitometric measurements described in Materials and Methods.

The maximal stimulation occurred with about $30 \mathrm{~min}$ of incubation at $30^{\circ} \mathrm{C}$ in the presence of $100 \mu \mathrm{g} / \mathrm{ml}$ PS and $200 \mu \mathrm{M}$ $\mathrm{Ca}^{2+}$ (Fig. $7 A$ ). A 2 min reaction time was subsequently adopted for standard reactions since it gave substantial stimulation and was well within the linear range of the time course curve. Phosphate, $22 \mathrm{pmol} / \mu \mathrm{g}$ purified protein, or approximately $1 \mathrm{~mol}$ phosphate/mol F1, was incorporated, assuming homogeneity (Fig. $7 A$ ). However, protein F1 could have up to 2 phosphor- 


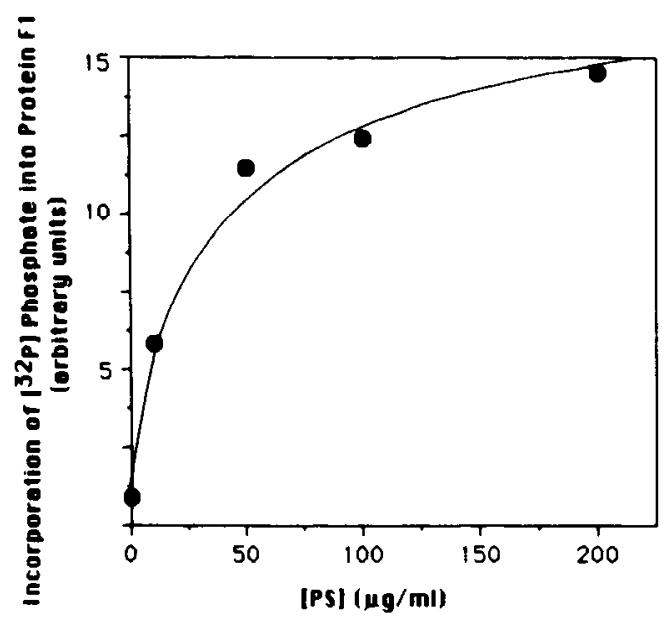

(A)

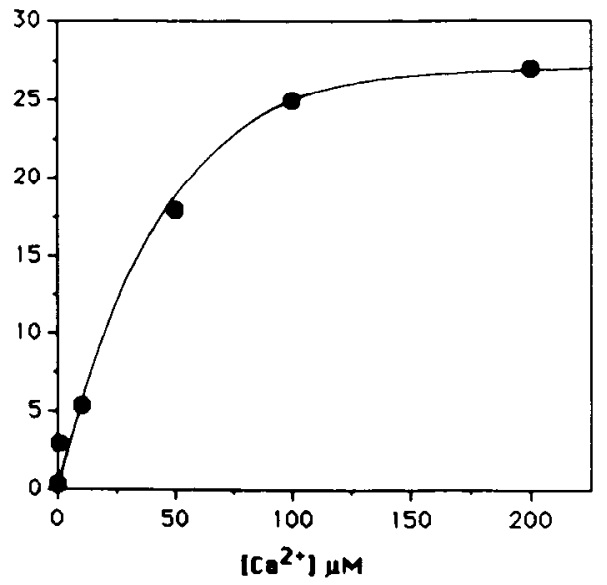

(B)
Figure 6. $\quad$ PS and $\mathrm{Ca}^{2+}$ dependence curves. $A$, PS dependence curve of protein F1 phosphorylation by PKC. Purified protein F1 fraction $(\sim 1 \mu \mathrm{g} /$ sample) was phosphorylated in the presence of $0-200 \mu \mathrm{g} / \mathrm{ml}$ PS. All samples contained $200 \mu \mathrm{M} \mathrm{Ca}{ }^{2+}$. Other conditions were the same as standard assay. Measurements were derived from densitometric scanning of autoradiographs. $B, \mathrm{Ca}^{2+}$ dependence curve of protein $\mathrm{F} 1$ phosphorylation by PKC. PS, $100 \mu \mathrm{g} / \mathrm{ml}$ was used in all samples, and $\mathrm{Ca}^{2+}$ concentration ranged from 0 to $200 \mu \mathrm{M}$. EGTA was used as a $\mathrm{Ca}^{2+}$ buffer at low $\mathrm{Ca}^{2+}$ concentrations ( $\leq 10 \mu \mathrm{M})$. ylation sites per molecule since the purified fraction contains only about $50-60 \%$ of the protein and no other PKC substrates are present in the fraction. The rate of $\mathrm{F} 1$ phosphorylation is comparable to that of histone $\mathrm{H} 1$, a known PKC substrate (Fig. $7, A, B)$. Diolein, $2 \mu \mathrm{M}$, or $2 \mu \mathrm{M}$ of the synthetic diacylglycerol 1,2-dioctanoylglycerol (DiC:8) in the presence of $\mathrm{PKC}$ and 100 $\mu \mathrm{g} / \mathrm{ml}$ PS lowered the requirement of $\mathrm{Ca}^{2+}$ for maximal phosphorylation of protein $\mathrm{Fl}$ by $\mathrm{PKC}$ from 100 to $5 \mu \mathrm{M}$.

\section{Isoelectric point}

Figure 8 presents an autoradiograph from IEF-SDS 2-dimensional gel analysis which shows that protein $F 1$ is an acidic protein with an isoelectric point of 4.5. Figure 8 also shows the distinctive microheterogeneity of phospho-F1, which suggests multiple-site phosphorylation of this protein. These characteristics of purified F1 are similar to previous results from our laboratory obtained from crude synaptosomal plasma membranes (Nelson and Routtenberg, 1985). It should be noted that the B-50 protein ( $\mathrm{p} I$ also about 4.5 ) was reported to have multiple forms (Zwicrs et al., 1985).

\section{Calmodulin inhibition of protein $\mathrm{Fl}$ phosphorylation}

We have found that protein $\mathrm{F} 1$ phosphorylation by $\mathrm{PKC}$ was inhibited by calmodulin. In the presence of $200 \mu \mathrm{M} \mathrm{Ca}^{2+}, 3.6$ $\mu_{M}(80 \mu \mathrm{g} / \mathrm{ml})$ calmodulin could inhibit $95 \%$ of the F1 phosphorylation under standard assay conditions (Fig. 9). The experiment was repeated using histone as a substrate in order to demonstrate that calmodulin was an inhibitor of PKC. Under the standard kinase assay conditions (see Materials and Methods), $95 \mu \mathrm{g} / \mathrm{ml} \mathrm{CaM}$ inhibited about $80 \%$ of histone $(1 \mu \mathrm{g} / \mathrm{ml})$ phosphorylation by PKC. Increased substrate concentration $(300$ $\mu \mathrm{g} / \mathrm{ml}$ histone) reversed calmodulin's inhibitory effect. The inhibition of both PKC substrates by calmodulin suggests that it directly interacts with PKC. It is possible that CaM serves as an intracellular regulator of $\mathrm{PKC}$ substratcs, including protcin F1 (see Discussion).

\section{Site of phosphorylation and phosphopeptide mapping}

In order to determine the nature of the phosphoamino acid residues on protein $F 1$, the phosphorylated protein was acid
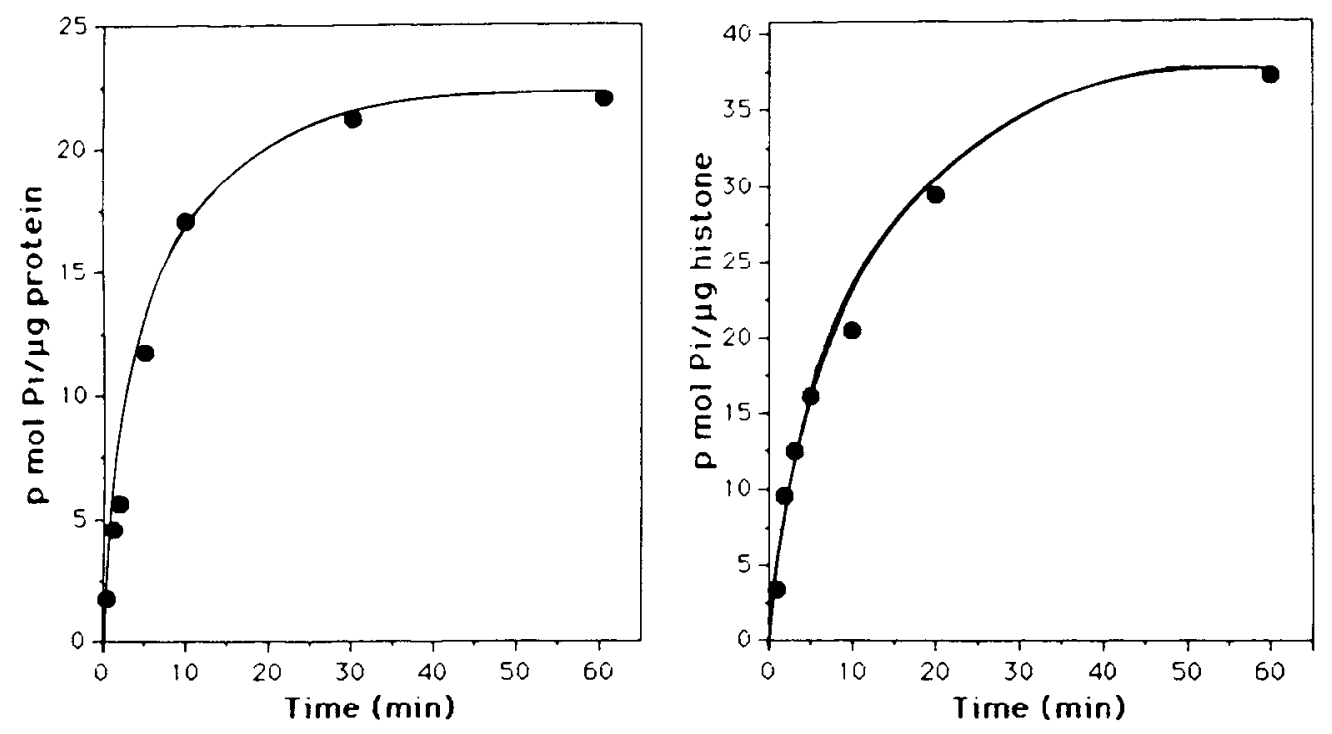

(A)
Figure 7. Time dependence of phosphorylation. $A$, Rate of protein $\mathrm{Fl}$ phosphorylation by PKC. Approximately $1 \mu \mathrm{g}$ protein per sample. PS, $100 \mu \mathrm{g} / \mathrm{ml} ; \mathrm{Ca}^{2+}, 200 \mu \mathrm{M}$; and ${ }^{32} \mathrm{P}-$ ATP, $25 \mu \mathrm{M}$, were present in all samples. Phosphate incorporation (in pmol) was calculated from dpm counts in excised F1 bands. $B$, Rate of histone $\mathrm{Hl}$ (type III-S) phosphorylation by PKC. Histone content, $20 \mu \mathrm{g} / \mathrm{sam}$ ple. The protein/enzyme ratio and other conditions were the same as for $A$ except that phosphocellulose paper assay (see Materials and Methods) was used instead of SDS-PAGE. 


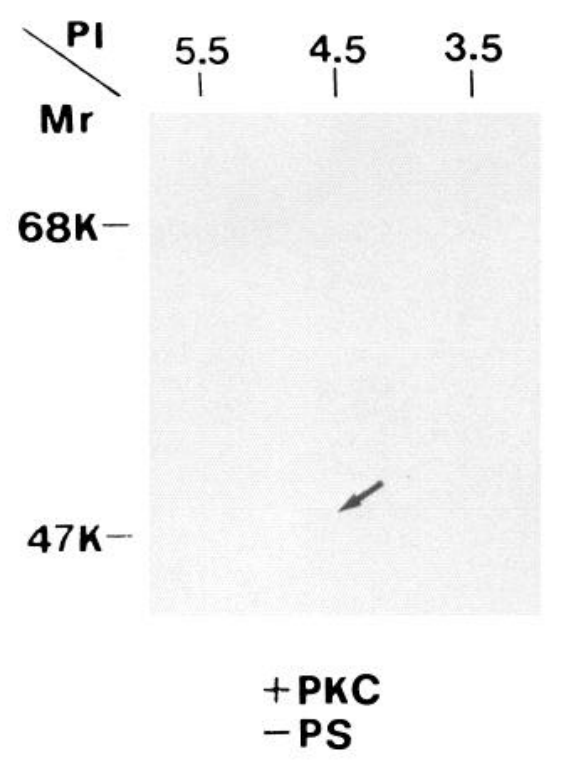

(A)

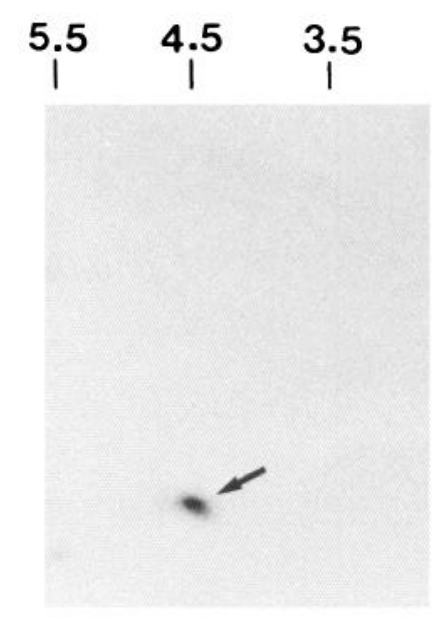

+ PKC
+ PS

(B)

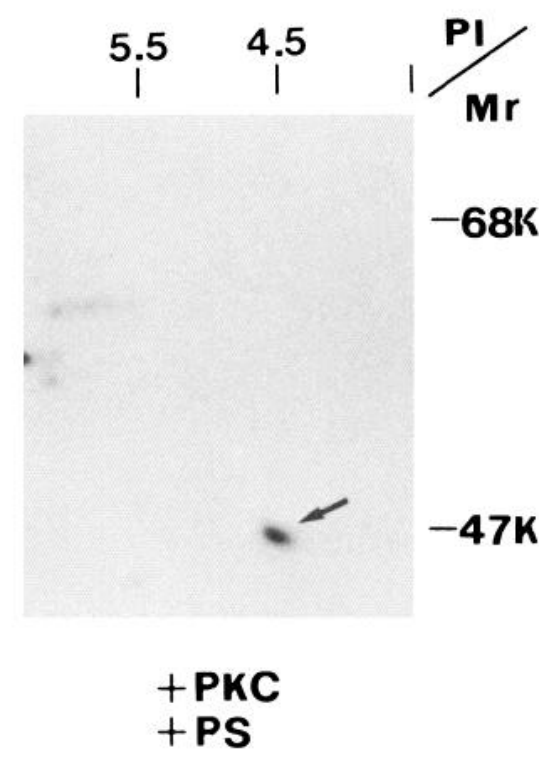

(C)

Figure 8. Two-dimensional gel showing the isoelectric point and microheterogeneity of phospho-F1. $A$, Purified F1 fraction, $1 \mu \mathrm{g}$, phosphorylated under standard assay conditions but without PS. No PKC-stimulated protein F1 phosphorylation was found at the expected position (arrow). $B$, Same as $A$ except that $100 \mu \mathrm{g} / \mathrm{ml}$ PS was added. Protein F1 was phosphorylated and showed a distinctive microheterogeneity that featured an elongated band with 1 tail tilting upward toward the alkali end. The $\mathrm{p} I$ was found to be 4.5 . $C$, Same as $B$ except that $5 \mu \mathrm{g}$ of the HP $30-75 \mathrm{~mm}$ KPi eluate was used instead. Arrows indicated the expected position of protein F1.

hydrolyzed after separation from PKC using SDS-PAGE (see Materials and Methods). This step was necessary since PKC was autophosphorylated during the reaction. Of the total ${ }^{32} \mathrm{P}$-phosphate incorporated into protein F1, most was associated with the serine residue. Quantitative comparison by counting the cutoff phosphoamino acid bands showed that $97 \%$ of the incorporated phosphate was associated with phosphoserine and

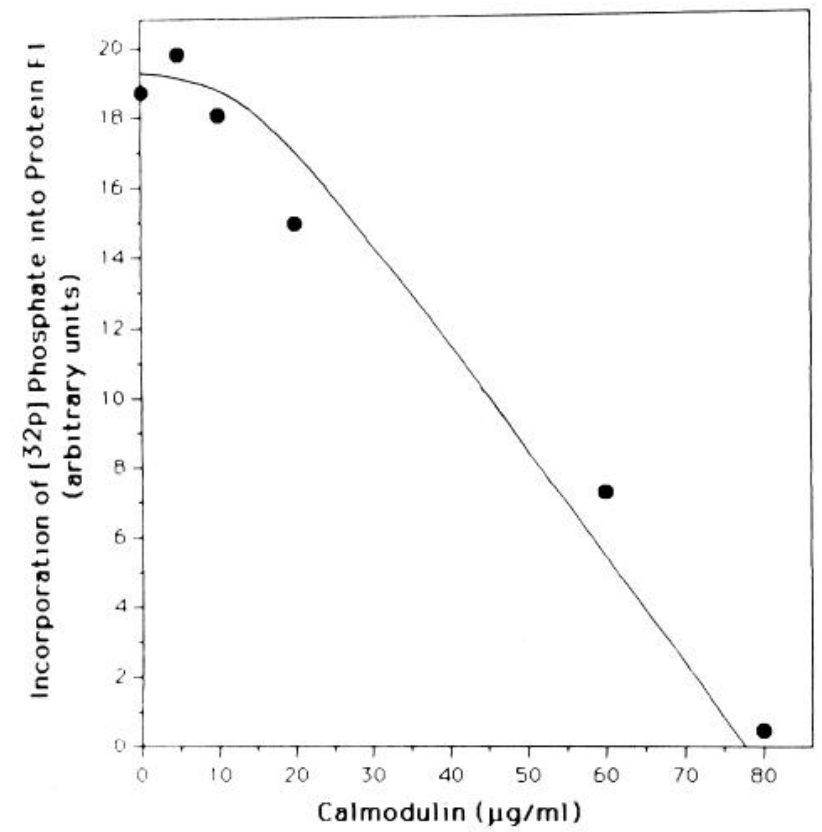

Figure 9. Calmodulin inhibition of F1 phosphorylation. Between 0 and $80 \mu \mathrm{g} / \mathrm{ml}$ calmodulin was added to the otherwise standard phosphorylation conditions. Free $\mathrm{Ca}^{2+}, 200 \mu \mathrm{M}$, was present during the reaction. At $80 \mu \mathrm{g} / \mathrm{ml}$, calmodulin inhibited almost $100 \%$ of the F1 phosphorylation by PKC.
$3 \%$ with other amino acids. The autoradiograph showed no detectable radioactive phosphate in either tyrosine or threonine (Fig. 10).

For phosphopeptide mapping, phenyl-Sepharose-purified protein F1 was phosphorylated under optimal conditions and subjected to SDS electrophoresis. Protein F1 bands were identified by autoradiography and excised from dried gel. After swelling and elution of protein from the gel slices, phospho-F1 was proteolyzed using $200 \mu \mathrm{g} / \mathrm{ml} S$. aureus V8 protease as described in Materials and Methods. The proteolyzed fragments were run on a $20 \%$ gel. The subsequent autoradiography showed 2 phospho-fragments having apparent molecular masses of 13,000 and 11,000 (Fig. 11). The 11,000 Da band seemed to be much broader than the 13,000 Da band (see Discussion). Molecular masses were calculated from the gel mobility of the fragments with respect to marker proteins of known molecular weight.

\section{Other properties}

Following the procedure of Swallow et al. (1977), a concanavalin A column was used to test if protein F1 was a glycoprotein. Protein Fl did not bind to the column (data not shown), arguing against the possibility that it is a glycoprotein.

Exogenous cAMP-dependent kinase did not stimulate phosphorylation of purified protein F1 (data not shown). Some evidence indicates that calmodulin stimulates protein F1 phosphorylation in crude synaptosomal membranes (Nelson et al., 1985), which raises the possibility that protein F1 may be a substrate of a Ca-calmodulin kinase as well. We have tested purified Ca-calmodulin kinase type II (gift of Dr. M. Kennedy) and partially purified Ca-calmodulin kinase type I (according to the procedure of Kennedy and Greengard, 1981) as possible candidates. However, no phosphorylation of protein F1 by either of these kinases was observed (data not shown).

\section{Discussion}

A number of nerve-associated phosphoproteins described by different laboratories are remarkably similar to the physical and 

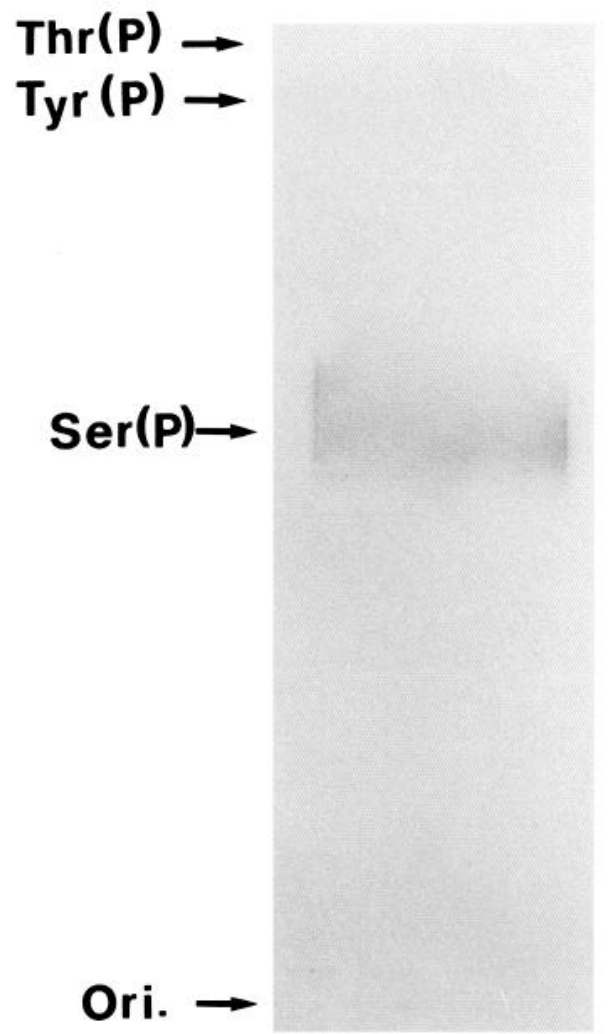

Figure 10. Autoradiograph showing the phosphoamino acid residues of phospho-F1. Some $97 \%$ of the radioactive phosphate was incorporated into the serine residues as a consequence of $F 1$ phosphorylation by PKC. Judging from the autoradiograph, there was no labeling at the threonine site.

biochemical characteristics of protein $\mathrm{F} 1$. These proteins include rat brain B-50 protein (Oestreicher et al., 1983; Zwiers et al., 1980), GAP43 (Skene, 1984; Skene and Willard, 1981a, b), and fetal growth cone pp46 phosphoprotein (Katz et al., 1985; Pfenninger et al., 1983). In recent collaborative studies, protein F1 was found to cross-react with anti-B50 (Gispen et al., 1986) and anti-GAP 43 (Snipes et al., 1986) antisera and to have similar, if not identical, properties to pp46 (Nelson et al., 1985). Thus, based on existing evidence of co-identification, protein $\mathrm{F} 1$ is likely to be involved in nerve growth and regeneration, as well as in synaptic plasticity (Routtenberg, 1985a).

Protein F1 is undoubtedly associated with synaptosomal membranes (Fig. 1). However, based on the phenyl-Sepharose column elution profile, protein $\mathrm{F} 1$, unlike PKC, was observed to be a very hydrophilic molecule. It is possible that protein F1 is a hydrophilic subunit of a macromolecular complex. This possibility was consistent with our observation that protein F1, a 47,000 Da protein, was eluted at the void volume of a P-200 gel-filtration column. However, several attempts using analytical gels without SDS to resolve this issue have failed to yield a higher-molecular weight complex. An alternative explanation may be that protein F1 exists as a complex of 47,000 Da subunits. Further effort will be made to clarify this point.

Protein F1 was observed to be phosphorylated almost exclusively on phosphoserine. Kawahara et al. (1980) described a membrane-bound 40,000 Da PKC-stimulated platelet phosphoprotein, the phosphorylation of which is closely correlated with secretion of 5-HT and platelet granule constituents. This protein has since been purified by Imaoka et al. (1983), who referred to it as P47, and the phosphoamino acid residues were found to be mostly serine. On the other hand, it was recently found that the amino acid residues of human EGF-R phosphor-
$\mathbf{M r}$

$-68 K$

$-47 K$

$-29 K$

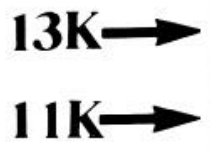

$-14 K$

Figure 11. S. aureus V-8 protease phosphopeptide mapping. Autoradiograph showing radioactive fragments of protein $\mathrm{F} 1$ as separated by a $20 \%$ SDS gel. The molecular masses of the phosphopeptides were calculated from the mobility of marker proteins with known molecular weight. Arrows indicate the approximate positions of the 2 phosphofragments. The marker proteins used were albumin $(68,000 \mathrm{Da})$, fumarase $(47,000 \mathrm{Da})$, carbonic anhydrase $(29,000 \mathrm{Da})$ and $\alpha$-lactoalbumin $(14,200 \mathrm{Da})$.

ylated by PKC was primarily threonine (Cochet et al., 1984; Hunter et al., 1984; Iwashita and Fox, 1984), in contrast with P47 and protein F1. EGF-R internalization can be induced by PMA-induced PKC phosphorylation of a specific threonine site near the cytosolic membrane surface (Beguinot et al., 1985). Such internalization differed from EGF-induced internalization, which led to the degradation of the receptor in lysosomes. Different classes of PKC substrates related, for example, to receptors or secretion may, in turn, be related to specific patterns of amino acid residues being phosphorylated. Unfortunately, insufficient evidence is available to relate specificity for phosphoamino acid residues of PKC substrates to their functional role. Using myelin basic protein as a model substrate, Kishimoto et al. (1985) have recently initiated the study of PKC substrate specificity and its relation to functional consequence.

Proteolysis using V8-protease yielded 2 broad bands of approximate $M_{\mathrm{r}}$ of 13,000 and 11,000 (Fig. 11). A possible explanation for the broadness was revealed in recent experiments from our laboratory using 2-dimensional gel analysis of the phosphofragments, which indicated that there were several polypeptides of slightly different molecular weights and isoelectric points derived from each of these bands (R. B. Nelson and A. 
Routtenberg, unpublished observations). The lower-molecularweight region contained a greater diversity of phosphorylation spots, which could explain why the lower band was broader. This observation could be related to the multiple phosphorylation site phenomenon of protein B- 50 described by Zwiers et al. (1985).

Calmodulin, $3.5 \mu \mathrm{M}$, inhibited $90 \%$ of protein $\mathrm{F} 1$ phosphorylation by PKC. It is likely that calmodulin affects $\mathrm{PKC}$, rather than protein $F 1$, in view of reports by others showing calmodulin inhibition of other PKC substrates (Albert et al., 1984). Kojima et al. (1984) recently proposed a 2-branch involvement of the angiotensin II-stimulated aldosterone secretion system in adrenal glomerulosa cells. The calmodulin branch, activated by transient rises in free cytosolic $\mathrm{Ca}^{2+}$, was responsible for the initial phase of aldosterone secretion, while the PKC branch, regulated by transient increases in intramembrane diacylglycerol, was responsible for the sustained phase of this cellular event. Such an interpretation is relevant to the finding in our laboratory that a selective increase of in vitro endogenous protein $\mathrm{Fl}$ phosphorylation was seen $5 \mathrm{~min}$ and $1 \mathrm{hr}$, but not 1 min, after long-term potentiation (Lovinger et al., 1985, 1986; Routtenberg et al., 1985) and the concurrent translocation of PKC activity from cytosol to plasma membrane (Akers et al., 1986). These observations, along with the recent demonstration of phorbol ester enhancement of synaptic plasticity (Routtenberg et al., 1986) suggest that the increase in endogenous F1 phosphorylation is due to an increase in membrane PKCactivity and that PKC-mediated system(s) may be responsible for the sustained or long-term phase of the process. Calmodulin, in addition to its activation of kinases, could be responsible for inhibition of PKC activation and, thus, protein Fl phosphorylation in the early phase of long-term potentiation.

Purification by relatively nondenaturing methods has the potential advantage that the isolated protein may retain its bioactivity. Isolation and characterization of protein F1 will also permit the immunological identification with protein molecules characterized by others and the study of the underlying mechanism responsible for the observed increase of in vitro phosphorylation after long-term potentiation. Such convergent information may then lead to the elucidation of its specific physiological role in the nervous system.

\section{References}

Akers, R., and A. Routtenberg (1985) Protein kinase C phosphorylates a $47 M_{\mathrm{r}}$ protein (F1) directly related to synaptic plasticity. Brain Res. 334: 147-151

Akcrs, R., D. Lovinger, P. Colley, D. Linden, and A. Routtenberg (1986) Translocation of protein kinase $C$ activity after long-term potentiation may mediate hippocampal synaptic plasticity. Science 231: 587-589.

Albert, K. A., W. C.-S. Wu, A. Nairn, and P. Greengard (1984) Inhibition by calmodulin of calcium/phospholipid-dependent protein phosphorylation. Proc. Natl. Acad. Sci. USA 81: 3622-3625.

Ames, G. F.-L. (1974) Resolution of bacterial proteins by polyacrylamide gel electrophoresis on slabs. J. Biol. Chem. 249: 634-644.

Beguinot, L., J. A. Hanover, S. Ito, N. D. Richert, M. C. Willingham, and I. Pastan (1985) Phorbol esters induce transient internalization without degradation of unoccupied epidermal growth factor receptors. Proc. Natl. Acad. Sci. USA 82: 2774-2778.

Cleveland, D. W., S. G. Fischer, M. W. Kirschner, and U. K. Laemmli (1977) Peptide mapping by limited proteolysis in sodium dodecyl sulfate and analysis by gel electrophoresis. J. Biol. Chem. 252: 11021106.

Cochet, C., G. N. Gill, J. Meisenhelder, J. A. Cooper, and T. Hunter (1984) C-kinase phosphorylates the epidermal growth factor receptor and reduces its epidermal growth factor-stimulated tyrosine protein kinase activity. J. Biol. Chem. 259: 2553-2558.

Davis, R. J., B. R. Ganong, R. M. Bell, and M. P. Czech (1985a) sn1,2-Dioctanoylglycerol. A cell-permeable diacyglycerol that mimics phobol diester action on the epidermal growth factor receptor and mitogenesis. J. Biol. Chem. 260: 1562-1566.
Davis, R. J., B. R. Ganong, R. M. Bell, and M. P. Czech (1985b) Structural requirements for diacylglycerols to mimic tumor-promoting phorbol diester action on the epidermal growth factor receptor. J. Biol. Chem. 260:5315-5322.

De Robertis, E., G. R. de Lores Arnaiz, M. Alberici, R. W. Butcher, and E. W. Sutherland (1967) Subcellular distribution of adenyl cyclase and cyclic phosphodiesterase in rat brain cortex. J. Biol. Chem 242: 3487-3493.

Gispen, W. H., P. N. De Graan, S. Y. Chan, and A. Routtenberg (1986) Comparison between the neural acidic proteins B-50 and $F_{1}$. In Phosphoproteins in the Nervous System, Vol. 69, W. H. Gispen and A Routtenberg, eds., Elsevier/North Holland, Amsterdam (in press).

Gopalakrishna, R., and W. B. Anderson (1982) $\mathrm{Ca}^{21}$ induced hydrophobic site on calmodulin: Application for purification of calmodulin by phenyl-Sepharose affinity chromatography. Biochem. Biophys. Res. Commun. 104: 830-836.

Hunter, T., N. Ling, and J. A. Cooper (1984) Protein kinase C phosphorylation of the EGF receptor at a threonine residue close to the cytoplasmic face of the plasma membrane. Nature 311:480-483.

Imaoka, T., J. A. Lynham, and R. J. Haslam (1983) Purification and characterization of the 47,000-dalton protein phosphorylated during degranulation of human platelets. J. Biol. Chem. 258: 11404-11414.

Iwashita, S., and C. F. Fox (1984) Epidermal growth factor and potent phorbol tumor promotors induce epidermal growth factor phosphorylation in a similar but distinctively different manner in human epidermoid carcinoma A431 cells. J. Biol. Chem. 259: 2559-2567.

Katz, F., L. Ellis, and K. H. Pfenninger (1985) Nerve growth cones isolated from fetal rat brain: III. Calcium-dependent protein phosphorylation. J. Neurosci. 5: 1402-1411.

Kawahara, Y., Y. Takai, R. Minakuchi, K. Sano, and Y. Nishizuka (1980) Phospholipid turnover as a possible transmembrane signal for protein phosphorylation during human platelet activation by thrombin. Biochem. Biophys. Res. Commun. 97: 309-317.

Kennedy, M. B., and P. Greengard (1981) Two calcium/calmodulindependent protein kinases, which are highly concentrated in brain, phosphorylate protein I at distinct sites. Proc. Natl. Acad. Sci. USA 78: 1293-1297.

Kikkawa, U., Y. Takai, R. Minakuchi, S. Inohara, and Y. Nishizuka (1982) Calcium-activated, phospholipid-dependent protein kinase from rat brain. J. Biol. Chem. 257: 13341-13348.

Kishimoto, A., K. Nishiyama, H. Nakanishi, Y. Uratsuji, H. Nomura, Y. Takeyama, and Y. Nishizuka (1985) Studies on the phosphorylation of myelin basic protein by protein kinase $C$ and adenosine $3^{\prime}$ : 5 -monophosphate-dependent protein kinase. J. Biol. Chem. 260: 12492-12499.

Kojima, I., K. Kojima, D. Kreutter, and H. Rasmussen (1984) The temporal integration of the aldosterone secretory response to angiotensin occurs via two intracellular pathways. J. Biol. Chem. 259: $14448-14457$

Lovinger, D. M., R. F. Akers, R. B. Nelson, C. A. Barnes, B. L. Mcnaughton, and A. Routtenberg (1985) A selective increase in phosphorylation of protein $F 1$, a protein kinase $C$ substrate, directly related to three day growth of long term synaptic enhancement. Brain Res. 343: 137-143.

Lovinger, D. M., R. F. Akers, P. A. Colley, R. B. Nelson, and A. Routtenberg (1986) Direct relation of long-duration synaptic potentiation to phosphorylation of membrane protein Fl: A substrate for membrane protein kinase C. Brain Res. (in press).

Lowry, O., N. J. Rosebrough, and R. J. Randall (1951) Protein measurement with the Folin phenol reagent. J. Biol. Chem. 193: 265275.

Lubben, T. H., and J. A. Traugh (1983) Cyclic nucleotide-independent protein kinases from rabhit reticulocytes. Purification and characterization of protease-activated kinase II. J. Biol. Chem. 258: 1399213997.

Miles, M. F., P. Hung, and R. A. Jungmann (1981) Cyclic AMP regulation of lactate dehydrogenase: Quantitation of lactate dehydrogenase M-subunit messenger RNA in isoproterenol- and $\mathrm{N}^{6}, \mathrm{O}^{2}$. dibutyryl cyclic AMP-stimulated rat $\mathrm{C} 6$ glioma cells by hybridization analysis using a cloned cDNA probe. J. Biol. Chem. 256: 1254512552.

Morgan, D. G., and A. Kouttenberg (1981) Brain pyruvate dehydrogenase: Phosphorylation and enzyme activity altered by a training experience. Science 214: 470-471.

Murakami, K., and A. Routtenberg (1985) Direct activation of purified 
protein kinase $\mathrm{C}$ by unsaturated fatty acids (oleate and arachidonate) in the absence of phospholipids and $\mathrm{Ca}^{2+}$. FEBS Lett. 192: 189-193.

Nelson, R. B., and A. Routtenberg (1985) Characterization of protein F1 (47kDa., $4.5 \mathrm{pI}$ ): A kinase C substrate directly related to neural plasticity. Exp. Neurol. 89: 213-224.

Nelson, R. B., A. Routtenberg, C. Hyman, and K. H. Pfenniger (1985) A phosphoprotein (F1) directly related to neural plasticity in adult rat brain may be identical to a major growth cone membrane protein (pp46). Soc. Neurosci. Abstr. 11:927.

Nishizuka, Y. (1984a) The role of protein kinase $C$ in cell surface signal transduction and tumour promotion. Nature 308: 693-698.

Nishizuka, Y. (1984b) Turnover of inositol phospholipids and signal transduction. Science 225: 1365-1370.

Oestreicher, A. B., C. J. Van Dongen, H. Zwiers, and W. H. Gispen (1983) Affinity-purified anti-B-50 protein antibody: Interference with the function of the phosphoprotein B-50 in synaptic plasma membranes. J. Neurochem. 41: 331-340.

O'Farrell, P. 7., H. M. Goodman, and P. H. O'Farrell (1977) High resolution two-dimensional electrophoresis of basic as well as acidic proteins. Cell 12: 1133-1142.

Pfenninger, K. H., L. Ellis, M. P. Johnson, L. B. Friedman, and S. Somlo (1983) Nerve growth cones isolated from fetal rat brain: Subcellular fractionation and characterization. Cell 35: 573-584.

Routtenberg, A. (1985a) Protein kinase Cactivation leading to protein F1 phosphorylation may regulate synaptic plasticity by presynaptic terminal growth. Behav. Neural Biol. 44: 186-200.

Routtenberg, A. (1985b) Phosphoprotein regulation of memory formation: Enhancement and control of synaptic plasticity by protein kinase $C$ and protein F1. Ann. NY Acad. Sci. 444: 203-211.

Routtenberg, A. (1986) Synaptic plasticity and protein kinase C. In Phosphoproteins in the Nervous System, Vol. 69, W. H. Gispen and A. Routtenberg, eds., Elsevier/North Holland, Amsterdam (in press).

Routtenberg, A., D. M. Lovinger, and O. Steward (1985) Selective increase in the phosphorylation of a $47 \mathrm{kDa}$ protein $(\mathrm{F} 1)$ directly related to long-term potentiation. Behav. Neural Biol. 43: 3-11.

Routtenberg, A., P. Colley, D. Linden, D. Lovinger, and K. Murakami
(1986) Phorbol ester promotes growth of synaptic plasticity. Brain Res. 378: 374-378.

Schaffner, W., and C. Weissmann (1973) A rapid, sensitive, and specific method for the determination of protein in dilute solution. Biochemistry 56: 502-514.

Skene, J. H. P. (1984) Growth-associated proteins and the curious dichotomies of nerve regeneration. Cell 37:697-700.

Skene, J. H. P., and M. Willard (1981a) Changes in axonally transported proteins during axon regeneration in toad retinal ganglion cells. J. Cell Biol. 89: 86-95.

Skene, J. H. P., and M. Willard (1981b) Characteristics of growthassociated polypeptides in regenerating toad retinal ganglion cell axons. J. Neurosci. 1: 419-426.

Snipes, G. J., J. A. Freeman, B. Costello, S. Y. Chan, and A. Routtenberg (1986) Evidence that the growth-associated protein, GAP-43, and the plasticity-associated protein, protein Fl, are identical. Soc. Neurosci. Abstr. 12: 500.

Swallow, D. M., L. Evans, and D. A. Hopkinson (1977) Several of the adenosine deaminase isozymes are glycoproteins. Nature 269: 261-262.

Ueda, T., and P. Greengard (1977) Adenosine 3':5'-monophosphateregulated phosphoprotein system of neuronal membranes. I. Solubilization, purification, and some properties of an endogenous phosphoprotein. J. Biol. Chem. 252: 5155-5163.

Walsh, M. P., K. A. Valentine, P. K. Ngai, C. A. Carruthers, and M. D. Hollenberg (1984) $\mathrm{Ca}^{2+}$-dependent hydrophobic-interaction chromatography. Isolation of a novel $\mathrm{Ca}^{2+}$-binding protein and protein kinase $\mathrm{C}$ from bovine brain. Biochem. J. 224: 117-127.

Zwiers, H., P. Schotman, and W. H. Gispen (1980) Purification and some characteristics of an ACTH-sensitive protein kinase and its substrate protein in rat brain membranes. J. Neurochem. 34: 16891699.

Zwiers, H., J. Verhaagen, C. J. Van Dongen, P. N. de Graan, and W. H. Gispen (1985) Resolution of rat brain synaptic phosphoprotein B-50 into multiple forms by two-dimensional electrophoresis: Evidence for multisite phosphorylation. J. Neurochem. 44: 1083-1090. 